\title{
Videoarte y paisaje: la cultura como espectáculo
}

\section{Videoart and Landscape: the culture as a show}

TIPO DE TRABAJO: Comunicación.

PALABRAS CLAVE

Videoarte, contemporáneo, espectáculo, arte, cultura.

KEY WORDS

Videoart, Contemporary, Show, Art, Culture.

RESUMEN

Basándonos en las numerosas teorías acerca de la mercantilización de la cultura, la cultura de masas, la cultura como espectáculo o la popularización de la cultura pretendemos analizar las prácticas que, a través de los recursos del audiovisual -particularizando en el videoarte-, se están sirviendo de los aspectos formales del medio para promover esta sobreexposición de las imágenes. En esta comunicación reflexionaremos sobre una serie de obras que acuden a recursos que abrazan alarmantemente los códigos identificados por aquellos que hablan de la mutación de la cultura a un producto para satisfacer a las masas. Obras que parecen haber supeditado el contenido al contenedor. Elementos como la inmersión, la sensación de realidad, la velocidad, el audiovisual, la imagen en movimiento, la apelación sensorial o la manipulación emocional delimitaran el campo de estudio. Tras haber estudiado las prácticas artísticas que representan a la sociedad del Antropoceno desde su contenido, hemos obtenido otros resultados paralelos y no planeados. Aquí analizaremos estas prácticas en torno a sus aspectos formales.

\section{ABSTRACT}

Based on the many theories regarding the commercialization of the culture, the mass culture, the culture as a spectacle or the popularization of the culture we try to analyze the practices that, through the audiovisual resources -specifying on the videoart- are using the formal aspects of the media to promote the overexposition of the images. In this conference, we will reflect on a series of images that utilize the resources that alarmingly embrace the codes identified by those that denounce the mutation of the culture to a product to satisfy the masses. Works that look to have submitted the content to the container. Elements like the inmersion, the impression of reality, the speed, the audiovisual, the moving image, the sensorial appeal or the emotional manipulation will delimit the field of study. After have studied the artistic practices that represent the Anthropocenic society from its content, we have obtained other results no planified. Here we will analyze these practices regarding their formal aspects.

\section{INTRODUCCIÓN}

La proliferación de la imagen en nuestra sociedad ha dado lugar a una promiscua explotación de la misma y, en consecuencia, con frecuencia, a un detrimento de la calidad de su contenido. Esta sobreexposición, junto a la globalización, los valores que imperan en la sociedad mercantilista y la banalización actual de la cultura amenazan con llevar a nuestras prácticas artísticas hacia la misma degradación y puerilidad que reina hoy en muchas esferas de la sociedad. La sobreexposición, la obligación a hacer productos que lleguen a la máxima cantidad de público y los requisitos del mercado están arrastrando a nuestras prácticas artísticas hacia la "industria de la cultura" que, recordemos, no es lo mismo que "cultura". No pretendemos aquí hablar mal de nuestras prácticas artísticas que con tanta dedicación estudiamos, admiramos y valoramos, sino de la sociedad que las demanda y las recibe. El arte se sustenta en el "sistema del arte" -museos, galerías, curadores, ferias de arte...- y, por tanto, los artistas -consciente o inconscientemente- se supeditan a las leyes que imperan en el mercado de la oferta y la demanda. Esta conferencia trata sobre la 
preocupación que surgió de manera paralela en una investigación sobre el paisaje contemporáneo, al percatarse de cómo los intereses de la praxis contemporánea están sucumbiendo a los requisitos y al lenguaje de la sociedad del espectáculo.

Defino mi conjunto [n] como una serie de imágenes que comparten unas mismas propiedades: imágenes que responden a las exigencias que reclama la sociedad del espectáculo. Mi conjunto [n] está formado por ["El naufragio de los hombres" (2008) de Charly Nijensohn, "The Three Gorges" (2011) de Sonja Hinrichsen, “Espíritu Santo" (2013) de Gianfranco Foschino, "Imperial Valley" (2018) de Lukas Marxt y "The speed and eagerness of meaning" (2011) de Richard T. Walker]. Y mi cero, [0] = ["El naufragio de los hombres"]. Esta será la base para desarrollar las teorías que invitarán a reflexionar sobre la visibilidad y la sobreexposición de las imágenes en la era tecnológica. Y los restantes elementos de mi conjunto soportarán mi tesis.

Comencé mi investigación sobre paisaje y videoarte preguntándome cómo era la sociedad actual y cómo esta realidad se estaba reflejando en la praxis que está configurando una nueva tradición paisajística genuinamente contemporánea, con el fin de analizar la praxis. Pero, entonces, surgió una vía paralela al darme cuenta de que los aspectos formales que analizaba eran también el reflejo de la crisis civilizatoria que tantos eruditos están advirtiendo. Donde la simplicidad, efimeridad e inmediatez con alarmante frecuencia se anteponen al esfuerzo intelectual, la contemplación y la reflexión.

\section{METODOLOGÍA}

El presente trabajo es la obtención de resultados paralelos y no planificados de otro trabajo de investigación. Este trabajo inicial se centraba en estudiar las propuestas artísticas que aúnan videoarte y paisaje, defendiendo el surgimiento de un nuevo paisaje en el seno del arte contemporáneo. Tras analizar las obras, comenzaron a surgirnos preguntas en torno al discurso formal. Si bien es cierto que partíamos de la hipótesis de dotar de reconocimiento a paisajes que "sí definen a la sociedad actual", comenzamos a preguntarnos si estos recursos formales (como la inmersión, la apelación sensorial, la realidad aumentada o la continua búsqueda de sorprender en términos perceptivos, entre muchos otros rasgos) de verdad tenían que ver con los intereses del arte o si, por lo contrario, era el arte el que se estaba supeditando a una sociedad donde hasta lo ontológico ha sido mercantilizado y donde todo se considera un producto que debe adaptarse para llegar a todas las masas. Aunque el arte ha ido siempre de la mano del avance tecnocientífico, ¿hasta qué punto se estaba poniendo al servicio de "la sociedad del espectáculo»? Desde el respeto que sentimos hacia estas obras y artistas, comenzamos a leer a autores como Gilles Lipovetsky y Jean Serroy y su obra "La cultura-mundo" (2010), Guy Debord y sus 221 tesis reunidas en "La sociedad del espectáculo" (1967) o, de carácter más divulgativo, Mario Vargas Llosa su obra "La civilización del espectáculo" (2012). A la vez, otra serie de eventos que ya conocíamos volvieron a nuestra mente como el show -que no exposición- de Gustav Klimt celebrada durante 2018 en el Atelier des Lumièrs en París o, también, el espectáculo multimedia de Vincent Van Gogh que ha recorrido ya 45 ciudades por todo el mundo. Pero, también, por ejemplo, el Mori Building Digital Art Museum de Tokyo, inaugurado en 2018 surge a partir de las mismas premisas: experiencia y sensorialidad, con el arte de por medio como excusa. Así pues, sirviéndonos de las hipótesis que habíamos obtenido en nuestro trabajo de investigación, junto a las teorías sostenidas por los autores arriba citados y tomando como ejemplos los eventos que acabamos de nombrar, construimos la base ideológica para las teorías que en esta comunicación presentaremos.

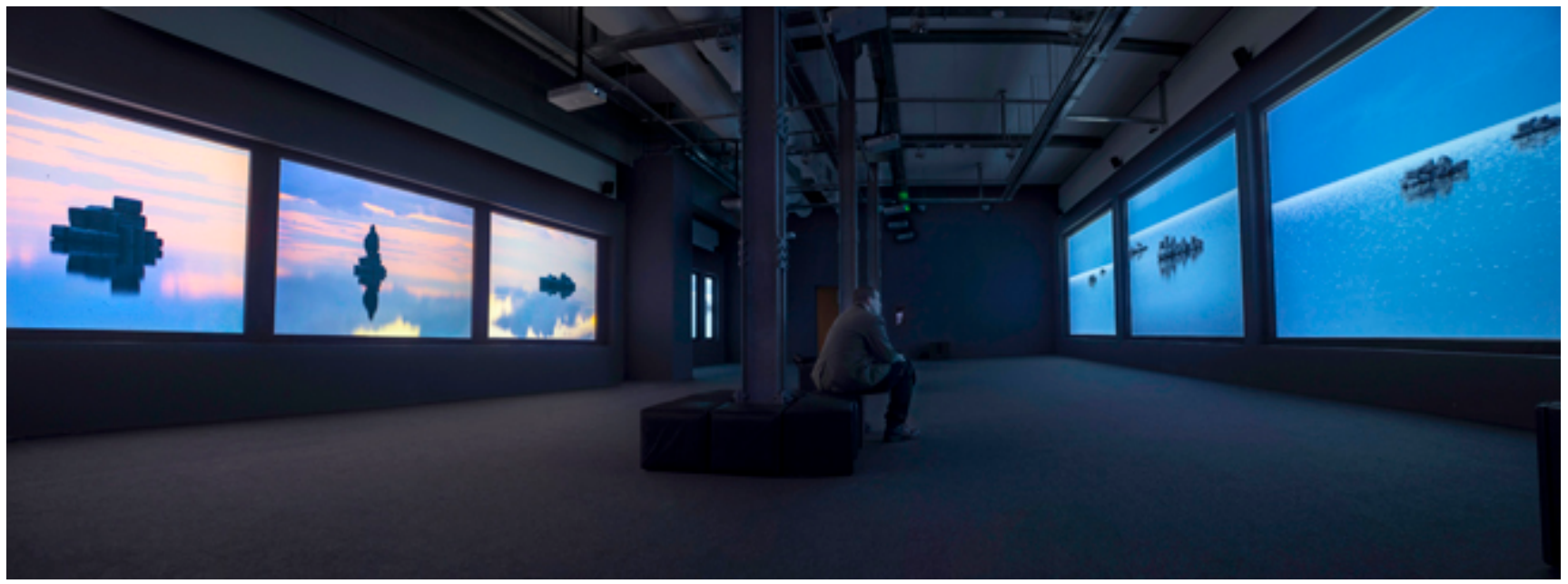

Figura 1. "El naufragio de los hombres" (2008), Charly Nijensohn, en la Fundación Telefónica. 


\section{DESARROLLO}

"El naufragio de los hombres" (2008) de Charly Nijensohn (Figura 1) es una videoinstalación de tres proyecciones registrada en el altiplano boliviano, en el Salar de Uyuni, inundado durante los meses de lluvia. Un espacio en el que los valores de la luz alteran cualquier percepción debido a la altura, la temperatura y el reflejo de la sal. Un desierto blanco configurado como una tierra de nadie que se confunde con un paisaje polar, aunque este aparente hielo sea de agua y sal (AA.VV., 2014, p.45). Las características de la obra y la estética de las imágenes ya confunden al espectador, quien no sabe muy bien donde está y se siente sumergido en un paisaje surrealista. En una habitación a oscuras, rodeado de pantallas gigantes y del sonido envolvente se presentan estas imágenes que te hacen perder la noción entre lo ilusorio y lo real. Imágenes en las que, a nivel conceptual, el autor te invita a perderte para encontrarte. Esta obra es pura lírica audiovisual. Y, aunque sus características formales impresionen por la puesta en escena, la estética representada y el carácter empírico, a nivel conceptual la obra se supera a sí misma. Conceptualmente encontramos una tridimensionalidad de espacio, tiempo y existencialismo. Las obras de Nijensohn siempre esconden un mensaje muy crítico y reivindicativo. También un fuerte mensaje metafísico. Así como obliga al espectador a detenerse, a contemplar y a reflexionar.

Nuestra imagen cero reúne estas características generales que acabamos de nombrar y que se repiten en el resto de nuestras imágenes aquí seleccionadas (Figura 2). Cada una guarda un mensaje particular, una crítica o una reflexión. Y es que, si bien es cierto que a nivel formal nos preocupan sus códigos y lenguajes de representación que parecen aproximarse cada vez más a los que reclama "la sociedad del espectáculo", también es cierto que llegamos a todas estas obras por su contenido, en un intento de estudio del paisaje contemporáneo. Por tanto, estas son obras que, a pesar del empleo del lenguaje audiovisual, del empirismo, de la sensorialidad, de las desproporcionadas dimensiones de sus imágenes y de la inmersión aún mantienen un discurso de índole conceptual de alto nivel intelectual. Lo que nos preocupa y que aquí intentamos advertir es hasta qué punto van a seguir incorporando estos recursos tan alarmantemente comerciales y hasta qué punto van a supeditar la calidad del contenido en pro de las formas para impresionar al espectador. Puesto que vivimos en una cultura multisensorial, donde siempre se busca la novedad y el impacto en el espectador, y donde los sentidos siempre están en el foco de la experimentación (Di Bella, 2018, p. 104). Una cultura donde las pantallas se han colado en cada rincón de nuestras vidas y las imágenes [en movimiento] lo han hecho con ellas (Lipovetsky y Serroy, 2009). Esto reclama una mayor atención en su contenido y discurso para no caer en una cierta desartistización de la imagen en movimiento.

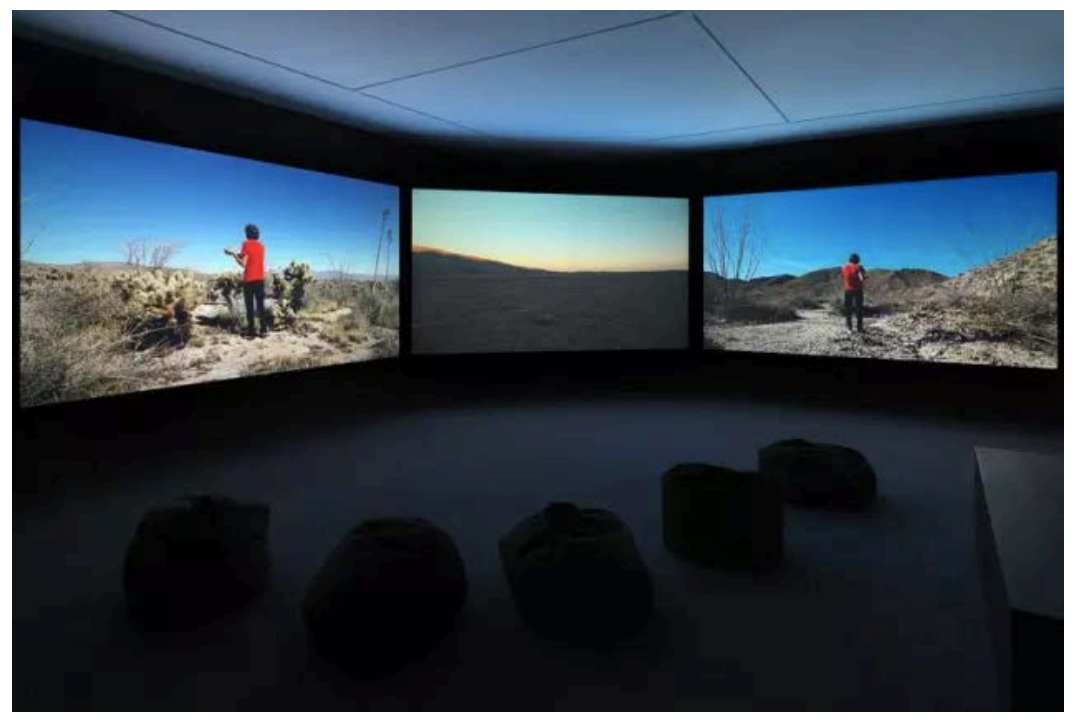

Figura 2. "The speed and eagerness of meaning" (2011) de Richard T. Walker

Sin embargo, la sobreexposición y la promiscuidad del uso de la imagen en movimiento se evidencia aún más en las imágenes que nacen y mueren en el mero consumo y que parten de los mismos principios que aquí acabamos de nombrar (inmersión, imagen en movimiento, imágenes de dimensiones colosales, sensorialidad, impacto, percepción...). Son productos donde el esfuerzo intelectual ha sido arrebatado en pro del espectáculo, en pro de la impresión. Hablamos, por ejemplo, de espectáculos multimedia como el show de Gustav Klimt celebrado durante 2018 en el Atelier des Lumièrs en París (Figura 3) o del espectáculo multimedia de Vincent Van Gogh que va recorriendo los cinco continentes. Ambos se anuncian como "exposición" pero, a pesar de servirse de la imagen en movimiento y de la historia del arte, y de anunciarse como "exposiciones de arte" este tipo de shows no pertenecen al mundo de la cultura, sino al mundo de la industria del espectáculo. Donde prima la experiencia y el asombro, cual espectador que va a ver una función del "Circo del Sol" -con todo el respeto hacia este tipo de espectáculo, pero, encajándolo en la categoría que le corresponde-. 
Este tipo de shows multimedia son un claro ejemplo de la sobrexposición de la imagen y la desvalorización de la imagen y del video. Donde se rompen -y casi desprecian- todos los códigos del videoarte y de la pintura (dado que las imágenes usadas, como Klimt y Van Gogh, provienen del campo de la pintura). Un último ejemplo sería el Mori Building Digital Art Museum de Tokyo, inaugurado en 2018 en la ciudad de Tokyo. Este es un museo de arte digital -para presentar un caso que no sea acerca de la imagen en movimiento-, pero que, sin duda, se fundamenta, nuevamente, sobre los conceptos de inmersión y sobreexposición. A los directores y curadores del museo no les bastó la simple imagen de arte digital, sino que recrean un espacio donde se viva una experiencia, donde se "sobre" exponga el arte y las imágenes y donde el individuo se sienta inmerso, perdido, envuelto. Si bien estos conceptos pueden parecer muy interesantes desde la disciplina de la historia del arte, la realidad es que habla mucho de la sociedad para la que están pensados. Y preocupa que al ponerlos al servicio del público y del mercado, los valores positivos que los especialistas podamos encontrar en estas prácticas corren el riesgo de malinterpretarse y mal utilizarse, especialmente en una cultura que desprecia la reflexión en pro del vistazo, y la foto en pro de la idea.

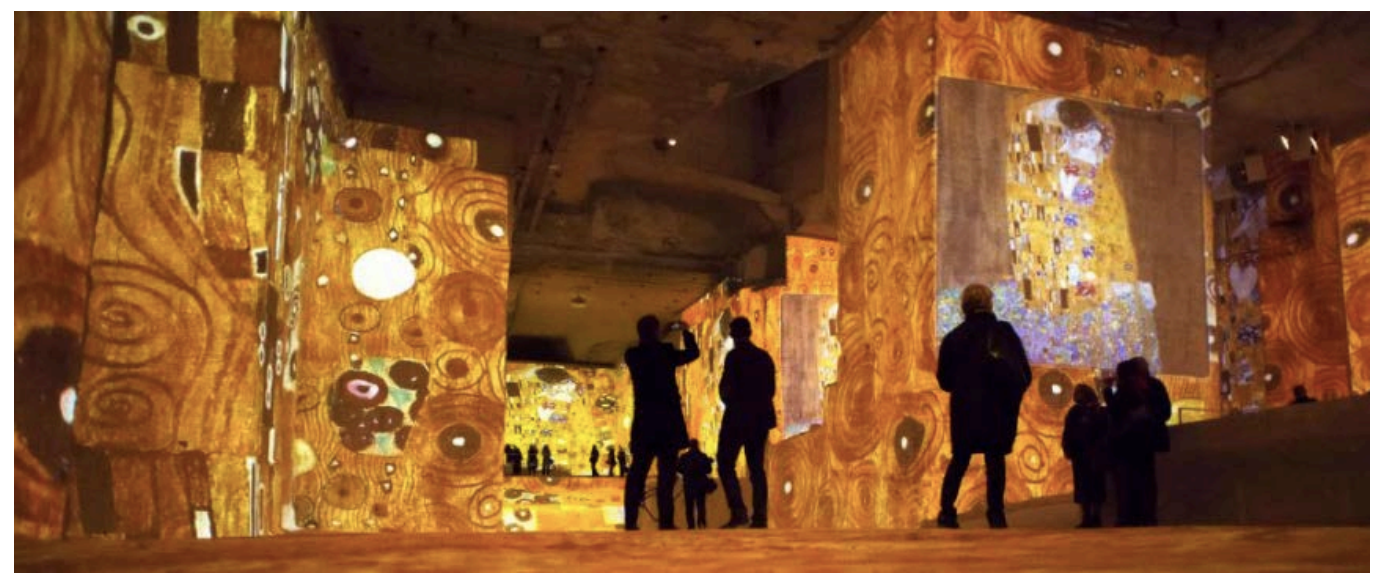

Figura 3. Exposición multimedia de Gustav Klimt.

\section{CONCLUSIONES}

Si bien es cierto que comenzamos esta investigación intentado estudiar aquellos paisajes que sí definían a la sociedad de su tiempo, defendiendo que la estética romántica había quedado atrás y que ahora existían nuevos paisajes cuyas pulsiones de orden temático, formal, conceptual y estético eran genuinamente contemporáneas y, por tanto, debíamos dejar los referentes paisajísticos de las composiciones clásicas atrás, lo cierto es que en un estado ya avanzado de la investigación nos comenzó a inquietar el poder y el protagonismo que adquirían ciertos recursos del formato video. El efecto inmersivo y envolvente buscado con frecuencia, la manipulación emocional, los efectos del audiovisual, la apelación sensorial, el juego entre lo real y lo ilusorio, la realidad aumentada o la continua búsqueda de sorprender en términos perceptivos, entre muchos otros efectos, crearon en nosotros una cierta preocupación al ver cómo el videoarte y la imagen en movimiento podían estar aproximándose cada vez más hacia el lenguaje del espectáculo y comprometiendo el reconocimiento de la artistización que tanto ha costado alcanzar a este medio, cosa que llegamos a probar con algunos ejemplos. En ocasiones, los artistas estaban dando un papel protagonista a las características que caracterizan a aquellos productos pensados y diseñados para llegar a todas las masas y relegando el discurso intelectual a un segundo lugar. Hemos presentando una serie de obras cuyo discurso conceptual aún les protege de la banalización, pero somos conscientes de que no ocurre así siempre. Y que muchas obras empiezan a fundamentarse sobre estos efectos que tanto atraen a todo tipo de público en lugar de en el esfuerzo intelectual de las ideas que puedan transmitir a través de su trabajo. Es por ello por lo que sentimos la preocupación de advertir de que, si no prestamos atención, podemos estar destruyendo la imagen en movimiento desde dentro. Del mismo modo que sentimos la responsabilidad de dar a conocer este riesgo y advertir al mundo del arte mediante los ejemplos de Klimt o Van Gogh de la degradación a la que podemos llegar si seguimos supeditando la impresión a la idea o la sensación a la reflexión.

\section{FUENTES REFERENCIALES}

AA.VV. (2014). “Charly Nijensohn. Estado de emergencia”. Buenos Aires: Fundación Telefónica.

Di Bella, D. (2018). Exobra, la rematerialización de la imagen en movimiento. Cuadernos del Centro de Estudios en Diseño y Comunicación, ㄲo 66. 
Lipovetsky, G. y Serroy, J. (2010). La cultura-mundo. Barcelona: Anagrama.

Lipovetsky, G. y Serroy, J. (2009). La Pantalla global: cultura mediática y cine en la era hipermoderna. Barcelona: Anagrama.

Debord, G. (1995). La sociedad del espectáculo. Santiago de Chile: Naufragio.

Vargas Llosa, M. (2012). La civilización del espectáculo. Madrid: Alfaguara. 